Sustainability Governance in the Enlarged European Union: The Applicants' View

\title{
The Myth of the End of Progressive Environmental Policy
}

Mit dem Abschluss der Beitrittsverhandlungen hat eine neve Phase begonnen. Die Dominanz der EU sollte nun schrittweise einer ausgeglicheneren Beziehung zwischen alten und neven Mitgliedsstaaten weichen. Wird dies, wie teilweise von westlichen Autoren befürchtet wird, zu einer Abschwächung der europäischen Umwelt- und Nachhaltigkeitspolitik führen? Angesichts der Orientierung der wenigen Experten, die die Umweltpolitik der Beitrittsländer prägen, ist dies kaum zu erwarten. Zwar ist eine proaktive Politik unwahrscheinlich, doch wenn, dann werden sich die neven Mitglieder aus historischen Gründen eher an den umweltpolitisch führenden Staaten orientieren.

W

Von Petr Jeblicka ith the closure of negotiations for the environmental chapter of the acquis, a new phase of interaction between the European Union (EU) and Central and East European (CEE) accession countries is about to begin. Post-accession, the strong leverage that the EU exerted on candidate states should gradually be reduced so that an altered set of relations may emerge in which the new members have more resources and political opportunities for pursuing their own interests and priorities. Thus, it is now appropriate to try to identify the interests and priorities that may shape CEE states' approach to EU environmental policy in the future.

The existing accounts of the enlargement's impact on EU environmental policy adopt a top-down perspective, rely mostly on EU-related variables, and largely neglect the applicant states' perspective, their domestic variables, and the interests and priorities that may be relevant for their influence at the EU level. With one exception (1), the views of environmental policy communities in the CEE accession countries on future directions of EU environmental policy have so far been absent in these debates.

Few dissenting voices notwithstanding (2), it is generally assumed in the existing literature that eastern enlargement will inevitably lead to a downward pressure on EU environmental policy (3). These countries are expected to give an overriding priority to economic development over stringent environmental policy. It is also assumed that the new member states will either try to block the adoption of new environmental legislation or press for lower standards. A related assumption is that they will coordinate their conservative stance in the Environment Council not only among themselves but also with south European members.

Let us first take a look at the figures: According to the allocation of voting rights by the Treaty of Nice, the combined vote of CEE members in 2007, when also Romania and Bulgaria are expected to join the Union, will be 101 voting rights out of the total of 345. Even with 51 additional voting rights of Spain, Greece and Portugal, this alliance is short of 103 voting rights required to reach the qualified majority threshold of 255 voting rights (4). While it is impossible for the new members to control decision-making in the Council, with their 101 votes they can form a blocking minority.

Drawing on insights arising from two research projects (5) aimed at soliciting views of environmental policy experts in Hungary, Poland, Slovakia and the Czech Republic (the original four so-called Visegrad countries - V4), this article seeks to supplement this view of eastern enlargement's implications for EU environmental policy with the accession states' perspective.

What complicates this assessment is the near impossibility to identify EU integration-related interests of CEE accession countries other than full membership in the Union. Neither CEE governments nor their expert community have considered their post-accession environmental strategy. This lack of articulation provides the potential for unpredictable outcomes. Hence, what follows should be understood as an attempt at identifying contours of CEE countries' approach to post-accession EU environmental policy based on views of experts from the $\mathrm{V} 4$ group.

\section{- A Small and Closed Group of Ex- perts of CEE Environmental Policy}

V4 countries lack powerful domestic actors in environmental politics. Environmental NGOs are small and depend on external financial assistance. Although a significant part of their funding is EU-based, NGOs in V4 countries have not shown much interest in Europe-wide environmental policy, mainly because most funding aims to strengthen domestic capacity. The activity of the main domestic actors of EU environmental policy - the poorly resourced EU departments within environment ministries - is limited to administering the process of harmonization, with the implementation of the acquis as a maximal goal. There is no evidence of proactive strategies, or the development of novel or indigenous concepts of environmental policy. V4 countries' ability to participate in Brussels' environmental politics is likely to be undermined by a lack of experts with appropriate training and experience. V4 governments failed to recognize the importance of their experts' training for their future roles in the EU. The educational background of most $\mathrm{V} 4$ experts in narrow technical and scientific disciplines is not necessarily the most suitable one for their participation in complex political negotiations. $V 4$ countries lack think tanks and other research institutions of EU environmental policy. EU assistance programmes have also failed to prepare V4 experts for their participation in processes at the EU level as they were aimed at strengthening domestic implementation capacity. As a consequence, environmental policy communities in V4 countries are small and closed groups of experts that developed on the basis of expertise applicable at the sub-national or national levels. Most of them believe that the environmental $a c$ quis meets their countries' needs, in particular in the areas of water and air pollution and waste management. They also regard national implementation of the acquis as a major innovation in environmental policy. The majority of $\mathrm{V} 4$ experts reject the idea that pre-1989 environmental policy is relevant within the framework of the EU-V4 policy dialogue. Some environmentally positive practices of V4 countries, such as lower production of household waste per capita, recycling, wider use of public transport and, in some cases, 
less intensive forms of agriculture, inherited from the socialist period, have mainly negative connotations. If at all, it seems that the only innovative policy contributions in an enlarged EU that could emerge out of V4 group are in the areas less tainted by their association with Communism's constraints on personal consumption such as nature and landscape conservation, forest management and land use planning. However, these ideas remain at the general level as no effort is being made to convert them into policy proposals transferable to the EU.

\section{- The Reality of Cooperation}

Rather than command-and-control legislation, the policy preferred by $\mathrm{V} 4$ experts relies on new policy instruments including market-based instruments and horizontal legislation including access to information and stakeholders' participation. Given the deeply unfavourable context for such policy styles in V4 states, including underdeveloped civil society, the acceptance of new modes of environmental governance by V4 experts may seem striking. However, concepts such as flexibility, freedom of information and market-based instruments symbolise a break with the socialist model of bureaucratic environmental regulation. Despite their similar history, common environmental problems and the shared goal of EU membership, V4 countries have not engaged in any form of systematic cooperation in the area of environmental harmonization with the $\mathrm{EU}$, apart from formal meetings of environment ministers. The lack of mutual information about the process of harmonization within the V4 group and the minimal degree of contact among their experts is striking. As distance from the fall of the socialist system grows, environmental policy priorities are becoming more diverse (e.g. water management in Hungary and landscape conservation and forest management in Slovakia).

\section{The Future: Following the Leaders, not the South}

As to V4 states' future alliance politics, V4 experts unanimously ruled out alliances with south European countries in the Environment Council. The experts did not anticipate coordination within the $\mathrm{V} 4$ group in the post-accession period either. Nor did they expect a stable pattern of voting behaviour of their countries in the Environment Council. In their view, individual V4 countries would behave in an ad hoc manner, depending on specific opportunities and interests rather than on any systematic strategy. The marginal attraction of south European countries as allies is explained by their negligible involvement in CEE transformation. Instead, if any discernible alliance pattern occurs, V4 countries are expected to be generally oriented to EU environmental leaders such as the Netherlands, Denmark, Germany and Austria. This is based on cultural and geographical proximity, the intensity of current economic relations, and the post-1989 environmental assistance these countries provided to the $\mathrm{V} 4$ group.

\section{Conclusion}

It can be concluded that due to the weak domestic base of environmental policy, it is highly unlikely that CEE countries are - in the short term - capable of adopting a proactive approach to environmental policy-making at the EU level when they become full members. Environmental policy community in CEE accession countries neither expects nor requires any major changes - based on indigenous experiences - to this model. The strengthening of their environmental capacity facilitated by various EU assistance programmes - has centered on policy implementation at the domestic level, rather than enhancing CEE states' ability to influence the EU. The EU Commission's insistence on the full adoption of the environmental acquis with only a limited number of transition periods, is likely to lead to a relatively high degree of harmonization.

The expectations about CEE states joining the group of southern members and the expected consequent brake on the future development of EU environmental policy may be premature and should be qualified. CEE states have not and do not seem likely to coordinate their strategies, either among themselves or with south European member states. They would rather align themselves with the 'pioneer' member states that have been most active in transferring environmental know-how and have made environmental policy discourse in CEE countries largely compatible with their policy models. Given the technocratic nature of CEE societies, this co-operation may primarily occur in areas where significant improvement can be achieved by technological progress such as in renewable energy.

The currently preferred environmental policy outcomes in CEE countries correspond closely with the trend in the EU towards flexibility, economic instruments, stakeholder participation, and sectoral integration. An area in which integration is felt as most urgent is the interface between the environ- ment and transport. It is slightly ironic that those practices inherited form the Communist period, that were in some respects quite close to the ideal of sectoral integration such as the preference for public transport based on economic incentives, have been abandoned so lightmindedly.

\section{References}

(1) Regional Environmental Centre: Applicant Countries' Contribution to the 6th Environmental Action Programme. Szentendre 2000, Download: www.rec.org/REC/ Programs/6thEAP

(2) E.g. von Homeyer, I.: The Impact of Enlargement on EU Environmental Policy. In: Crisen, S.A.-M., Carmin J. (Hrsg.): EU Enlargement and Environmental Quality. Woodrow Wilson Center, 2002.

(3) E.g. Holzinger, K./ Knoepfel, P.: The Need for Flexibility. European Environmental Policy on the Brink of Eastern Enlargement. In: Holzinger, K./ Knoepfel, P. (Hrsg.), Environmental Policy in a European Union of Variable Geometry? Basel 2000, S. 3-35.

(4) Bobay, F: Political Economy of the Nice Treaty: Rebalancing the EU Council, Download: www.cepii.fr/anglaisgraph/ communications/pdf/2001/ffa25260601/bobay.pdf

(5) The project No. EU/043/99 was funded by the Czech Ministry of the Environment, the project №. RB 5/14/00 by the Czech Ministry of Foreign Affairs. The author acknowledges the collaboration of A. Tickle and I. Rynda. The author worked on earlier drafts of this paper while holding a Jean Monnet Fellowship at the European University Institute in Florence.

\section{Der Autor}

Dr. Petr Jehlicka ist nach einer Promotion an der Universität Prag zurzeit Lecturer für Umweltgeografie an der Open University im britischen Milton Keynes. Kontakt: Faculty of Social Sciences, The Open University, Walton Hall, Milton Keynes MK7 6AA, UK. Tel. 0044-1908-652130,E-Mail: P.Jehlicka@open.ac.uk

\section{Inserieren Sie in Ökologisches Wirtschaften!}

Sprechen Sie genau Ihre Zielgruppe an. Gesamtauflage von 2.500 Heften. Erscheint $5 \times$ jährlich.

Fordern Sie noch heute die Mediadaten an!

Frau Katja Muchow berät Sie gerne.

\section{Kontakt:}

Katja Muchow c/ o INKA e.V.

Gravelottestr. 6, 81667 München

Fon 089/45 911919 , Fax 089/4591 1920

E-Mail anzeigen@katja-muchow.de 
(c) 20I0 Authors; licensee IÖW and oekom verlag. This is an article distributed under the terms of the Creative Commons Attribution Non-Commercial No Derivates License (http://creativecommons.org/licenses/by-nc-nd/3.o/), which permits unrestricted use, distribution, and reproduction in any medium, provided the original work is properly cited. 